\title{
Analisis Dampak Krisis Pangan terhadap Human Security di Etiopia
}

\author{
Falhan Hakiki ${ }^{1}$ \\ ${ }^{1}$ Hubungan Internasional, Universitas Padjadjaran, Indonesia, hakikifalhan@gmail.com
}

\begin{abstract}
ABSTRAK
Etiopia merupakan negara yang telah sering mengalami krisis pangan akibat dari beberapa faktor seperti kekeringan, El Nino, hingga konflik militer yang menyebabkan kelaparan dan malnutrisi hingga menimbulkan korban jiwa. Pada artikel ini, penulis menganalisis dampak krisis pangan yang terjadi di Etiopia yang mengakibatkan terganggunya human security di Etiopia menggunakan konsep human security dan food security. Pada hasil analisis pertama, ditemukan krisis pangan berdampak kepada human security masyarakat Etiopia karena salah satu aspek human security, yaitu food security masyarakat Etiopia terganggu dan memberikan dampak terganggunya juga terhadap human security masyarakat Etiopia itu sendiri. Kemudian penulis menganalisis dampak dari krisis pangan terhadap human security di Etiopia dapat dari tiga dimensi Human Development Index (HDI), yaitu angka harapan hidup, standar hidup dan pendapatan, beserta tingkat pendidikan. Hasilnya menunjukkan bahwa dari tiga dimensi HDI, krisis pangan tidak memberikan pengaruh terhadap human security di Etiopia, walaupun krisis pangan mengakibatkan jatuhnya korban jiwa, penyakit, dan malnutrisi.
\end{abstract}

Kata Kunci: krisis pangan, human security, food security, Human Development Indeks

\section{ABSTRACT}

Ethiopia is a state that has experienced frequent food crises as a result of several factors such as drought, El Nino, to military conflicts that have caused hunger and malnutrition, causing casualties. In this article, the authors analyze the impact of the food crisis that occurred in Ethiopia which resulted in threat of human security in Ethiopia using the concepts of human security and food security. In the results of the first analysis, it was found that the food crisis had an impact on the human security of the Ethiopian community because one of the aspects of human security, namely the food security of the Ethiopian community was disturbed and had a disruptive impact on the human security of the Ethiopian community itself. Then the authors analyzed the impact of the food crisis on human security in Ethiopia from three dimensions of the Human Development Index (HDI), namely life expectancy, standard of living and income, along with education level. The results show that from the three dimensions of HDI, the food crisis has no impact on human security in Ethiopia, even though the food crisis has resulted in fatalities, disease and malnutrition.

Keywords: food crisis, human security, food security, Human Development Index

\section{Pendahuluan}

Setelah berakhirnya perang dingin, umumnya negara-negara di dunia telah memasuki era baru yang lebih damai dan sejahtera. Munculnya globalisasi dan liberalisasi perdagangan telah membantu terjadinya distribusi barang dan jasa, hingga setiap orang dapat menikmati kesejahteraan dan juga menjamin kelangsungan hidup mereka sendiri. ${ }^{1}$ Walaupun peperangan bukan lagi menjadi ancaman bagi kelangsungan hidup

\footnotetext{
${ }^{1}$ Ali M. Alli, Gregory S. Winter, and David L. May, "Globalization: Its Effects," International Business \& Economics Research Journal, Vol. 6, No. 1, p. 92, 2011.
} 
manusia, namun pada beberapa daerah di dunia ini masih terdapat ancaman yang datang dari berbagai faktor di luar perang, seperti krisis pangan, lingkungan, dan kesehatan. Hal ini kemudian mendorong munculnya human security atau keamanan manusia sebagai salah satu bidang kajian dalam ilmu hubungan internasional. Berbeda dengan keamanan klasik yang berpusat kepada negara, human security berpusat kepada keamanan dan kesejahteraan manusia.

Human security menurut PBB dalam Human Security Handbook nya ialah hak orang untuk hidup dalam kebebasan dan martabat, bebas dari kemiskinan dan keputusasaan. Menurut United Nations Trust Fund for Human Security, semua individu, khususnya orangorang yang rentan, berhak atas kebebasan dari ketakutan dan kebebasan dari apa yang diinginkan, dengan kesempatan yang sama untuk menikmati semua hak-hak mereka dan sepenuhnya mengembangkan potensi manusia mereka. $^{2}$ Menurut PBB, ada 7 aspek dalam human security, yaitu economic security, food security, health security, environmental security, personal security, community security, dan political security. ${ }^{3}$

Ketika satu aspek human security terganggu, maka dapat dikatakan human security seseorang juga akan terganggu. Begitu dengan kondisi yang terjadi di Etiopia. Ketika adanya kelaparan yang melanda Etiopia, maka

hal ini berdampak kepada salah satu aspek human security, yaitu food security, di mana terganggunya food security masyarakat Etiopia di akibatkan krisis pangan yang terjadi sehingga masyarakat Etiopia terhambat dalam pemenuhan aspek food security. Aspek yang menjadi perhatian di Etiopia ialah krisis pangan yang membuat adanya insecurity

\footnotetext{
${ }^{2}$ United Nations Trust Fund for Human Security, "Human Security Handbook: An integrated approach for the realization of the Sustainable Development Goals and the priority areas of the international community and the United Nations system," Human Security Unit United Nations, Januari 2016: p. 6.

${ }^{3}$ Ibid, p. 7.
}

terhadap food security. Hal ini terjadi di Etiopia bagaimana krisis pangan memberikan dampak terhadap human security itu sendiri, di mana hubungan antara human security dan food security didasarkan pada gagasan realisasi penuh hak asasi manusia atas kecukupan pangan, sebagai hak asasi manusia yang fundamental, dan hak asasi yang tidak meninggalkan siapa pun. Hak atas kecukupan pangan terwujud ketika setiap laki-laki, perempuan dan anak, sendiri atau dalam komunitas dengan orang lain, memiliki akses fisik dan ekonomi setiap saat atas pangan atau sarana yang memadai untuk pengadaannya. ${ }^{4}$

Etiopia merupakan sebuah negara yang terletak pada Timur Laut Afrika. Wilayahnya terkurung diantara negara-negara lain di Afrika. Dengan kondisi daerah yang gersang, Etiopia menjadi negara yang rawan akan bencana kekeringan yang mengakibatkan kelaparan. Di tahun 1973-1974 diperkirakan sekitar 250.000 warga Etiopia mati karena kelaparan, dan di tahun 1984-1985 hampir diperkirakan 1 juta warga Etiopia yang mati karena kelaparan ${ }^{5}$. Dan di masa yang sekarang, PBB memperkirakan sekitar 7,5 juta warga Etiopia terancam kelaparan $^{6}$, dan jika krisis kelaparan ini menjadi sangat serius, PBB melalui World Food Programme (WFP) memperkirakan 8 juta warga Etiopia segera akan membutuhkan bantuan makanan. ${ }^{7}$

\footnotetext{
${ }^{4}$ Food and Agriculture Organization of the United Nations, "Human Security \& Food Security," United Nations Human Security Unit, 2016: p. 3.

${ }^{5}$ Helmut Kloos and Bert Lindtjørn, "Malnutrition During Recent Famines in Ethiopia," Northeast African Studies, New Series, Vol. 1, No. 1, p. 21, 1994.

${ }^{6}$ Ruslan Burhan (ed), "Sekitar 7,5 juta penduduk Ethiopia kelaparan akibat El Nino," antaranews.com, 3 Oktober, 2015, https://www.antaranews.com/berita/521422/sekitar75-juta-penduduk-ethiopia-kelaparan-akibat-elnino, diakses pada 28 Agustus 2019.

${ }^{7}$ Maggie Miller, "Hunger in Ethiopia," p. 1, https://www.worldfoodprize.org/documents/filelibr ary/images/youth_programs/research_papers/2005 papers/NewLondonHighSchool_8D8BFDC1AE320 .pdf, diakses pada 28 Agustus 2019 .
} 
Pada rentang tahun 2015-2016, Etiopia terserang El Nino yang mengakibatkan krisis yang terjadi, baik itu krisis humanitarian serta kekeringan dan krisis pangan yang parah $^{8}$. El Nino merupakan pemanasan suhu permukaan laut di Pasifik tropis, terjadi kira-kira setiap 2 sampai 7 tahun, yang berlangsung dari 6 sampai 24 bulan, mengakibatkan berkurangnya curah hujan dan kekeringan, serta fenomena ini juga bisa mengakibatkan hujan lebat dan banjir bandang ${ }^{9}$. Etiopia sendiri mengalami kombinasi kekeringan yang buruk dan El Nino, di mana pada bulan Maret 2016, kekeringan di Etiopia masih berlangsung dan mempengaruhi daerah pertanian dataran tinggi dan daerah ternak dataran rendah. Dokumen Human Response Document 2016 meminta bantuan kemanusiaan yaitu makanan terhadap 10,2 juta penduduk Etiopia, dan sekitar 6 juta anak beresiko kelaparan, penyakit, dan kekurangan air di Etiopia sebagai akibat kekeringan terkait $E l$ Nino. ${ }^{10}$

Terdapat beberapa penelitian terdahulu yang membahas tentang krisis pangan dan dampaknya terhadap human security. Penelitian pertama yaitu dari Jenny Clover berjudul Food Security in Sub-Saharan Africa yang terdapat pada African Security Review volume 12 nomor 1 tahun 2003. Penelitian ini membahas hak atas pangan adalah salah satu hak yang paling konsisten disebutkan dalam dokumen hak asasi manusia internasional, tetapi hak itu yang paling sering dilanggar. Target yang ditetapkan oleh KTT Pangan Dunia pada tahun 1996 untuk pengurangan kelaparan sebagian besar telah gagal, meskipun produksi pangan telah tumbuh lebih cepat

\footnotetext{
${ }^{8}$ Food and Agriculture Organization, "El Niño in Ethiopia: Programme Observations on the Impact of the Ethiopia Drought and Recommendations for Action," OXFAM El Niño Briefings, 24 Februari 2016: p. 2.

${ }^{9}$ Food and Agriculture Organization of United Nations, "2015-2016 El Niño: Early Action and Response for Agriculture, Food Security and Nutrition," Working Draft, 9 Juli 2016: p. 1.

10 United Nations International Children's Emergency Fund, "Ethiopia El Nino Emergency," Fast Facts, April 2016.
}

daripada populasi dunia. Masalah keamanan global, nasional dan manusia semakin menyatu, dan di beberapa wilayah bertumpukan. Sekitar 840 juta orang di seluruh dunia kekurangan gizi, persentase tertinggi di Afrika. Besarnya masalah di Afrika kini telah mencapai tingkat krisis yang belum pernah terjadi sebelumnya, sekitar 38 juta orang menghadapi "ancaman yang mendesak dan segera terjadi terhadap perdamaian, keamanan, dan stabilitas mereka." Alasan mengapa rencana aksi untuk mengatasi ketahanan pangan terus gagal dapat dikaitkan dengan analisis yang salah dan tindakan yang salah. Apa yang dibutuhkan adalah pemahaman yang melampaui kebijaksanaan konvensional dan kuno untuk bekerja lebih strategis dalam mengembangkan dan menerapkan kebijakan internasional, nasional dan regional yang efektif. Ketersediaan, akses, dan keterjangkauan adalah semua elemen ketahanan pangan, masalah kompleks yang mencakup berbagai faktor ekonomi, sosial dan politik yang saling terkait, internal dan eksternal, yang menantang kemampuan Afrika untuk mengatasi ketahanan pangan. Pada akhirnya kelaparan adalah ciptaan politik yang harus diakhiri dengan cara politik. ${ }^{11}$

Penelitian kedua yaitu penelitian dari Abduselam Abdulahi Mohamed dengan judul Food Security Situation in Ethiopia: A Review Study yang terdapat pada International Journal of Health Economics and Policy volume 2 nomor 3 tahun 2017. Penelitian ini membahas kerawanan pangan adalah tantangan kritis yang bertahan lama di Etiopia yang merupakan negara berpenduduk kedua terbanyak di Afrika setelah Nigeria. Kekeringan El Niño 2015 merupakan salah satu kekeringan terkuat yang pernah tercatat dalam sejarah Etiopia di mana lebih dari 27 juta orang menjadi rawan pangan dan total populasi sebanyak 18,1 juta jiwa membutuhkan bantuan pangan pada tahun 2016. Selain itu, kekeringan dan degradasi

\footnotetext{
${ }^{11}$ Jenny Clover, "Food Security in Sub-Saharan Africa," African Security Review 12, No. 1, pp. 515, 2003.
} 
lahan, tekanan populasi, ketidakstabilan dan konflik bersenjata adalah sumber utama masalah food security di Etiopia. Untuk mengatasi masalah ini, orang Etiopia menggunakan penjualan ternak, pekerjaan pertanian, dan migrasi ke daerah lain, meminta pinjaman biji-bijian, penjualan kayu atau arang, perdagangan skala kecil dan membatasi ukuran dan frekuensi makan sebagai mekanisme penanganan utama. ${ }^{12}$

Terakhir, penelitian dari Bahlbi Y. Malk yang berjudul State-induced Famine in Eritrea: Persecution and Crime against Humanity terdapat pada Journal of Politics and Law volume 10 nomor 4 tahun 2017. Penelitian ini membahas kelaparan tetap menjadi salah satu penyebab utama kematian dan pemindahan di negara-negara Afrika Sub- Sahara di mana orang-orang terus menerus di paksa untuk melintasi perbatasan internasional untuk mencari jaminan mata pencaharian. Afrika juga telah terkena curah hujan yang tidak menentu, gagal panen dan kekeringan, tetapi kelaparan kontemporer tidak banyak berkaitan dengan kegagalan panen yang berhubungan dengan alam dan banyak hubungannya dengan tata kelola yang buruk.

Malk berpendapat bahwa tindakan negara yang direncanakan, kelambanan dan ketidakmampuan untuk menanggapi ketidakamanan dan ancaman sebagian besar bertanggung jawab atas kelaparan Afrika. Namun, karena kesalahan persepsi historis tentang kelaparan Afrika dan penyederhanaan motif pengungsi dari Afrika yang berlebihan, penganiayaan berbasis makanan belum menjadi subjek penelitian yang umum. Selain itu, tidak adanya kekeringan juga berarti tidak adanya kelaparan, karena faktor-faktor tersebut di atas sering kali menyebabkan terjadinya bencana bahkan di tengah banyaknya sumber daya. Oleh karena itu, tujuan dari tulisan Malk adalah untuk mengeksplorasi bagaimana

\footnotetext{
${ }^{12}$ Abduselam Abdulahi Mohamed, "Food Security Situation in Ethiopia: A Review Study," International Journal of Health Economics and Policy 2, No. 3, pp. 86-96, 2017.
}

tindakan atau kelambanan pemerintah dapat menyebabkan kelaparan jika tidak ada atau adanya kekeringan yang sebaliknya memaksa orang untuk melarikan diri dari kondisi kehidupan yang memburuk secara drastis melalui penerbangan. Tujuan dari penelitian Malk adalah untuk menantang persepsi umum bahwa kelaparan sebagai akibat dari krisis kemanusiaan yang disebabkan oleh kekeringan di Afrika dan pengungsi sebagai korban dari keadaan alamiah.

Dengan demikian, Malk berpendapat bahwa pemerintah yang mengambil paksa kebutuhan dasar warganya seperti hak atas pangan sama berbahayanya dengan pemerintah yang menganiaya warganya atas dasar lima Konvensi. Karenanya, mengambil Eritrea sebagai contoh kasus, penelitian Malk membahas ketidakamanan pangan kronis dan kelaparan massal sebagai bencana yang disebabkan oleh negara, di mana dianggap sebagai kejahatan terhadap kemanusiaan di bawah Statuta Roma dari Pengadilan Kriminal Internasional. ${ }^{13}$

Bencana kekeringan ditambah fenomena El Nino yang melanda Afrika Timur telah membuat pasokan makanan dan akses terhadap air bersih yang baik menjadi terbatas. Pasalnya, krisis ini telah merenggut ribuan jiwa dan menciptakan kerugian bagi orang lainnya. Kekeringan ditambah dengan fenomena $E l$ Nino, serta degradasi lahan, tekanan populasi, ketidakstabilan, dan konflik bersenjata mengakibatkan krisis pangan di Etiopia dan berdampak kepada terganggunya human security di Etiopia. Pada tulisan ini menganalisis bagaimana dampak krisis pangan terhadap human security di Etiopia itu sendiri.

\section{Human Security dan Food Security}

Isu human security berkembang dan mulai menjadi sorotan dunia internasional pasca perang dingin. Dengan berakhirnya

\footnotetext{
${ }^{13}$ Bahlbi Y. Malk, "State-induced Famine in Eritrea: Persecution and Crime against Humanity," Journal of Politics and Law 10, No. 4, pp. 1-14, 2017.
} 
perang dingin, keamanan yang dahulunya berfokus pada isu keamanan tradisional yang bersifat state-centered atau fokus kepada negara, kedaulatan, batas wilayah, dan aspek militer kemudian mengalami pergeseran pada keamanan non tradisional yang bersifat peoplecentered yang berfokus pada keamanan manusia (human security). Human security adalah sebuah isu yang universal, di mana ancamannya terjadi di seluruh negara di dunia dan dirasakan oleh seluruh manusia di dunia. Isu dari human security mencakup demokrasi, kemiskinan, penyakit, pelanggaran hak asasi manusia, pengangguran, polusi lingkungan, penggunaan narkotika, diskriminasi etnis, dan lain-lainnya. $^{14}$

United Nations Development Programme (UNDP) adalah lembaga PBB yang mencetuskan konsep human security dalam Human Development Report pada tahun 1994. UNDP mendefinisikan human security secara luas sebagai "freedom from fear" atau bebas dari rasa takut dan "freedom from want" atau bebas dari kekurangan. Dalam Human Development Report tahun 1994 juga dijelaskan bahwa human security adalah keamanan dari berbagai ancaman kronis seperti kelaparan, penyakit, dan represi, serta perlindungan dari gangguan mendadak dalam kehidupan seharihari baik di rumah, tempat kerja, ataupun komunitas. ${ }^{15}$

Berdasarkan Human Development Report tahun 1994, ancaman terhadap human security sangat banyak, tetapi dapat disederhanakan menjadi tujuh aspek utama, yaitu economic security, food security, health security, environmental security, personal security, community security, dan political security.

\footnotetext{
${ }^{14}$ United Nations Development Report Programme 1994 (pp. 22-23), New York: Oxford University Press, 1994.

${ }^{15}$ United Nations Trust Fund for Human Security, Human Security in Theory and Practice: An Overview of the Human Security Concept and the United Nations Trust Fund for Human Security (p. 9), New York: Human Security Unit, United Nations, 2009.
}

Economic security berupa pendapatan tetap yang harus didapatkan oleh setiap orang, bentuk ancamannya berupa kemiskinan. Food security fokus kepada kemampuan setiap orang untuk mendapat akses terhadap makanan dan ketersediaan pangan, bentuk ancamannya adalah kelaparan. Health security fokus pada bidang kesehatan yang berupa jaminan perlindungan dari penyakit dan gaya hidup tidak sehat, kemungkinan bentuk ancaman yang ditangani ialah penyakit menular yang mematikan, makanan yang tidak sehat, malnutrisi, serta kekurangan akses bagi masyarakat akan aspek-aspek dasar mengenai kesehatan. Environmental security fokus pada isu lingkungan seperti rendahnya akses air bersih, tingginya angka pencemaran dan polusi udara, pemanasan global, dan bencana alam. Personal security fokus untuk melindungi orang dari ancaman seperti kekerasan fisik, tindakan kriminal, terorisme, kekerasan domestik, serta tindakan mempekerjakan anak di bawah umur. Community security fokus pada masalah yang terjadi antar etnis, masalah antar agama, serta ketegangan yang ditimbulkan oleh masalah identitas. Political security berkaitan dengan lingkungan sosial yang mengarah pada hak asasi manusia, kemungkinan bentuk ancaman yang ditimbulkan ialah berupa penindasan yang bermotif politik serta penyalahgunaan hak asasi manusia. ${ }^{16}$

Ketujuh aspek tersebut saling berkaitan dan jika salah satu aspek tersebut terganggu, maka human security seseorang juga terganggu. Hal tersebut merupakan sebuah bentuk terganggunya food security di Etiopia yang berdampak pada terganggunya human security dan keberlangsungan hidup warga negara Etiopia. Mengutip pada World Food Summit, food security ialah keadaan di mana setiap orang mendapatkan akses secara fisik dan ekonomi untuk mendapatkan makanan yang cukup, aman, dan bergizi dalam

\footnotetext{
${ }^{16}$ United Nations Development Programme, New Dimensions of Human Security (pp. 24-33), New York: Oxford University Press, 1994.
} 
hal memenuhi kebutuhan makanan mereka untuk kehidupan yang aktif dan sehat. ${ }^{17}$

\section{Human Development Index}

Human Development Index (HDI) dapat diukur dengan melalui indikatorindikator seperti halnya pekerjaan, pendapatan, finansial, kesehatan, human security, demografi, pendidikan, kesetaraan gender, serta indikator lainnya. Dari semua indikator yang menjadi tolak ukur HDI tersebut terdapat tiga indikator penting, yaitu: angka harapan hidup, Gross National Income (GNI), dan angka melek huruf atau tingkat pendidikan. Untuk angka harapan hidup, dapat dilihat dari tingkat kelahiran penduduk suatu negara dan diiringi dengan tingkat kesehatan yang mampu menunjang kualitas kehidupan penduduk negara tersebut. GNI suatu negara pun ikut mempengaruhi HDI, yang mana indikator untuk pendapatan ini mampu menunjang kesejahteraan dan menggambarkan kemungkinan dari perkembangan serta pertumbuhan penduduk. Tidak hanya itu, pendidikan disuatu negara ikut menjadi faktor yang mampu menunjang peningkatan HDI itu sendiri. ${ }^{18}$

Dalam indikator HDI terkait persoalan pentingnya peningkatan kualitas hidup penduduk juga didapat bahwa Adam Smith memiliki pandangan akan alasan rasional seorang individu untuk hidup, tidak akan lepas dari human development itu sendiri, di mana human development yang kemudian menjadikan kehidupan seorang manusia itu lebih berkualitas dan cenderung untuk menjadi pertahanan seorang individu agar tetap hidup dengan segala indikator yang dimilikinya. ${ }^{19}$

\footnotetext{
${ }^{17}$ Food Agriculture Organization, "Food Security," Policy Brief, Juni 2006, p. 1.

${ }^{18}$ Human Development Report 2016, "Technical Notes, Calculating the Human Development IndicesGraphical Presentation," pp. 2-3.

${ }^{19}$ Sudhir Anand dan Amartya Sen, "The Income Component of the Human Development Index," Journal of Human Development 1, no. 1, p. 85, 2000.
}

Ketika semua negara telah mampu mencapai kesejahteraan penduduknya melalui peningkatan pada taraf-taraf kehidupan yang layak seperti tingkat pendidikan yang tinggi, pendapatan yang tetap bagi setiap penduduk yang memang seharusnya telah memungkinkan untuk meraih pendapatan, dan tingkat kesehatan penduduk disuatu negara tersebut. Adanya keterikatan antara HDI dengan indikatorindikator yang telah dijelaskan akan senantiasa menggambarkan fluktuatifnya HDI suatu negara dan bagaimana perbandingan HDI antar negara di dunia juga dapat dijelaskan melalui faktor-faktor tersebut. ${ }^{20}$

Untuk lebih jelas lagi bagaimana komponen-komponen yang terkandung didalam setiap indikator tersebut dapat dilihat dari halhal yang mampu menunjang peningkatan HDI seperti pada angka harapan hidup dapat dijelaskan komponen- komponennya yaitu nutrisi untuk kesehatan dan jumlah kematian pada anak-anak. Kemudian pada tingkat pendidikan dapat dijelaskan melalui hasil pendidikan itu sendiri dan kehadiran para siswa tersebut di sekolah. Seperti halnya untuk standar perkembangan hidup penduduk dapat tergambarkan melalui komponen-komponen seperti bagaimana kehidupan penduduk dalam kesehariannya. Hal ini terkait mobilisasi dan kelayakan hidup penduduk dalam pengurusan tempat tinggal, transportasi kemampuan untuk mencukupi kebutuhan sehari-hari, dan komponen lainnya pada setiap indikator yang telah dijelaskan. ${ }^{21}$

\section{Pembahasan}

\section{a. Kelaparan di Etiopia}

Kelaparan di Etiopia ancaman yang serius, khususnya terhadap human security di mana manusia pada hakikatnya membutuhkan

\footnotetext{
${ }^{20}$ United Nations Development Programme, Human Development Report 2015 (pp. 5-6). New York: RR Donnelley Company. 2015.

${ }^{21}$ Kpolovie, P. J., Ewansiha, S , dan Esara, M, "Continental Comparison of Human Development Index (HDI)," International Journal of Humanities Social Sciences and Education (IJHSSE) 4, 1, p. 12. Januari 2017.
} 
makanan untuk menopang asupan gizi sehingga dapat tumbuh dan berkembang secara maksimal, akan tetapi karena ancaman yang di timbulkan oleh kelaparan membuat akses untuk tumbuh dan berkembang dengan wajar menjadi terhalangi yang mengakibatkan salah satunya malnutrisi.

Kelaparan bukan hanya sekedar masalah antara makan atau tidak makan, akan tetapi ketika ancaman kelaparan terjadi maka dapat memicu terhadap bentuk ancaman lain seperti kesehatan. Menurut laporan UNICEF, lebih kurang 300.000 anak anak meninggal di Etiopia di akibatkan oleh malnutrisi pada tiap tahunnya. Hal ini berdampak kepada kesehatan karena anak-anak yang lapar sering kali mengalami pelemahan sistem kekebalan tubuh, kerusakan sistem syaraf, dan pertumbuhan fisik yang tidak normal, dan dampak ini dapat terjadi secara permanen bagi anak anak yang kelaparan. ${ }^{22}$

Menurut laporan Oxfam International pada tahun 2017, kerawanan pangan di Etiopia telah memburuk, mengakibatkan 700.000 orang terancam kelaparan. Sekitar 8,5 juta orang di Etiopia menghadapi resiko kelaparan yang tinggi, meningkat 30 persen sejak awal tahun. Kekurangan makanan dan kelaparan telah menyebabkan pengungsian dan mekanisme penanggulangan negatif seperti peningkatan pekerja anak, pernikahan dini dan putus sekolah, menurut laporan pemerintah Etiopia. ${ }^{23}$

Kelaparan mengakibatkan kondisi darurat gizi di Etiopia pada tahun 2018, khususnya pada kawasan selatan dan tenggara negara itu, dengan kantong-kantong kebutuhan di utara dan timur. Kebutuhan gizi tersebut disebabkan oleh kekeringan yang berkepanjangan, tingginya jumlah pengungsi internal dan tingginya kerawanan pangan. Secara nasional 350.111 anak membutuhkan

${ }^{22}$ Ibid., 2.

${ }^{23}$ Salem Solomon, "Oxfam: 700,000 at Risk of Starvation in Ethiopia," VOA News, 15 Agustus 2017, https://www.voanews.com/africa/oxfam700000-risk-starvation-ethiopia, diakses pada 7 Oktober 2020. pengobatan malnutrisi akut parah dan 3,48 juta orang membutuhkan pengobatan untuk malnutrisi sedang di 463 kota dan distrik. ${ }^{24}$

Sekitar 2,2 juta orang di Etiopia tetap mengungsi hingga akhir Mei 2019, menurut PBB. Faktor-faktor tambahan seperti kegagalan panen lokal, harga pangan yang tinggi, dan dampak kekeringan yang terus berlangsung di tahun-tahun sebelumnya telah berkontribusi pada prevalensi kerawanan pangan yang akut. Rencana Tanggap Kemanusiaan Etiopia memperkirakan bahwa sekitar 8,1 juta orang akan membutuhkan bantuan makanan darurat pada tahun 2019. ${ }^{25}$

Kelaparan di Etiopia, seperti yang spekulasikan oleh PBB karena curah hujan yang rendah di Etiopia, sementara bagi kelompokkelompok yang menyalurkan bantuan ke Etiopia, bantuan-bantuan tersebut terhambat dikarenakan akses yang terbatas, seperti keadaan politik yang memanas di mana adanya pertempuran antara pasukan pemerintah dan pemberontak. ${ }^{26}$ Selain itu, gagal panen di Etiopia merupakan salah satu bentuk penyebab kelaparan di Etiopia, mengakibatkan hargaharga bahan pokok dan pangan meningkat.

Penggantungan nasib pertanian terhadap hujan bukan satu satunya penyebab terjadinya kemiskinan dan kelaparan. Kelaparan memang disebabkan oleh

\footnotetext{
${ }^{24}$ World Vision International, "Responding to Food Insecurity in Ethiopia - March 2018," World Vision Online [home page on-line]; 20 April 2018, available from

https://www.wvi.org/ethiopia/publication/respondin g-food-insecurity-ethiopia-march-

2018\#: : :text=A\%20total\%20of $\% 20105 \% 2 \mathrm{C} 239 \% 2$ 0people,food\%20insecurity\%20in\%20March $\% 2020$ $18 . \&$ text $=$ The $\% 20$ nutrition $\% 20$ needs $\% 20$ are $\% 20$ ca used,persons $\% 20$ and $\% 20$ high $\% 20$ food $\% 20$ insecuri ty.; diakses pada 7 Oktober 2020.

${ }^{25}$ USAID, "Food Assistance Fact Sheet Ethiopia,"21 Agustus 2019.

${ }^{26}$ Ludger Schadomsky dan Vidi Legowo-Zipperer (eds Hendra Pasuhuk), "Krisis Kelaparan di Ethiopia," $d w$ news, 22 Juli, 2011, http://www.dw.com/id/krisis-kelaparan-diethiopia/a-15259579, diakses pada 29 Agustus 2019.
} 
kekurangan bahan pangan secara umumnya, akan tetapi ketika Etiopia punya kesempatan untuk meningkatkan taraf kehidupannya melalui uang, namun uang banyak dibelanjakan untuk mendukung pertempuran di medan perang, sehingga angka kelaparan di Etiopia meningkat. ${ }^{27}$

Dengan kelaparan yang terjadi di Etiopia, WFP sebagai salah satu badan yang menangani kelaparan di Etiopia menyimpulkan 10 fakta yang terjadi yang diakibatkan oleh timbulnya kelaparan di Etiopia, yaitu ${ }^{28}$ :

1. Lebih dari 2 dari 5 setiap anakanak di Etiopia menderita "stunting", di mana harapan untuk hidup mereka pendek. Stunting ialah kondisi di mana anak-anak kehilangan nutrisi penting mereka saat dalam kandungan atau selama lima tahun pertama kehidupan mereka.

2. Sebanyak $81 \%$ dari semua kasus gizi buruk anak di Etiopia tidak tertangani dengan baik.

3. $44 \%$ dari biaya kesehatan yang berhubungan dengan gizi buruk terjadi sebelum anak berusia 1 tahun.

4. $28 \%$ dari kematian anak di Etiopia terkait dengan gizi buruk.

5. $16 \%$ dari semua pengulangan di sekolah dasar terkait dengan stunting.

6. Anak-anak yang mengalami stunting memiliki 1,1 tahun keterlambatan terkait edukasi mereka di sekolah.

7. Kematian anak terkait dengan gizi buruk telah mengurangi ketenagakerjaan Etiopia sebesar $8 \%$.

\footnotetext{
${ }^{27}$ Maggie Miller, "Hunger in Ethiopia," 2.

${ }^{28}$ Website: World Food Programme. (24 Juni 2013). 10 Things Everyone Should Know About Hunger In Ethiopia. Diambil dari https://www.wfp.org/stories/10-things-everyoneshould-know-about-hunger-ethiopia (diakses pada 29 Agustus 2019).
}

8. $67 \%$ dari populasi orang dewasa di Etiopia juga menderita stunting dari anak-anak.

9. Anggaran tahunan yang dikeluarkan oleh pemerintah Etiopia 55,5 milyar Etiopia Birr dalam menangani gizi buruk. Hal ini setara dengan $16,5 \%$ dari GDP Etiopia.

10. Menghilangkan stunting di Etiopia adalah langkah yang diperlukan untuk pertumbuhan dan transformasi.

\section{b. Food Security dan Human Security di Etiopia}

Keterkaitan human security dan food security adalah food security merupakan aspek bagian dari human security. Ketika food security seseorang terganggu, maka hal tersebut berdampak kepada human security nya menjadi terganggu. Hal ini dapat di contohkan dengan kasus kelaparan di Etiopia yang mengakibatkan aspek food security masyarakatnya terganggu dan berdampak kepada human security nya.

Seperti yang di indikasikan oleh Africa Food Security and Hunger / Undernourishment Multiple Indicator Scorecard, Etiopia menduduki peringkat pertama yang memiliki jumlah penduduk kurang gizi atau kelaparan tertinggi yaitu 32,1 juta orang. Ini menjadikannya negara Afrika keempat dengan skor $(37,1 \%)$ dari populasi yang kekurangan gizi atau kelaparan. ${ }^{29}$ Mata pencaharian masyarakat pedesaan Etiopia sangat sensitif terhadap iklim. Pola kerawanan pangan bersifat musiman dan terkait dengan pola curah hujan, dengan tren kelaparan menurun secara signifikan setelah musim hujan. Guncangan terkait iklim mempengaruhi produktivitas, menghambat kemajuan ekonomi dan

\footnotetext{
${ }^{29}$ Mthuli Ncube, Charles Leyeka Lufumpa, Steve Kayizzi Mugerwa, and Victor Murinde, "Africa Food Security Brief: Special focus on climate Africa Food Security change Impacts," Africa Food Security Special focus on climate change Impacts Statistics Department Issue, No. 5, April 2014: p. 9.
} 
memperburuk masalah sosial dan ekonomi yang ada. ${ }^{30}$

Situasi kerawanan pangan di Etiopia sangat terkait dengan kekurangan pangan dan kelaparan yang berulang, yang terkait juga dengan kekeringan berulang. Saat ini ada konsensus yang berkembang bahwa kerawanan pangan dan masalah kemiskinan terkait erat dalam konteks Etiopia. Kekeringan dan bencana terkait lainnya (seperti gagal panen, kekurangan air, dan penyakit ternak, degradasi lahan, aset rumah tangga terbatas, pendapatan rendah) merupakan pemicu yang signifikan, faktor yang lebih penting yang meningkatkan kerentanan terhadap food security dan mata pencaharian yang berkurang. ${ }^{31}$

Selama beberapa dekade, masalah kerawanan pangan kronis dan sementara menjadi parah di Etiopia. Kerawanan pangan kronis terjadi karena tingginya rasio pengangguran perkotaan dan keterbatasan kepemilikan lahan pedesaan. Lebih dari sepertiga rumah tangga memiliki kurang dari 0,5 hektar, yang di bawah pertanian tadah hujan, cukup untuk produksi subsisten tanaman pangan. Kurangnya hewan penarik seperti lembu meningkatkan kerentanan yang terkait dengan perkebunan plasma yang berlebihan. ${ }^{32}$

El Niño yang berlangsung April / Mei 2016, memperburuk kerawanan pangan yang disebabkan oleh musim paceklik yang akan datang. Lebih dari 15 juta orang diperkirakan membutuhkan bantuan kemanusiaan pada tahun 2016. Rumah tangga miskin di daerah yang terkena dampak di zona Afar, di zona Hararghe Timur dan Barat di Oromiya, dan di Wag Hemra dan Utara Wollo di wilayah Amhara, diperkirakan akan tetap dalam

\footnotetext{
${ }^{30}$ Stephen Anderson and Elisabeth Farmer, "USAID Office of Food for Peace Food Security Country Framework for Ethiopia FY 2016 - FY 2020," Washington, D.C.: Food Economy Group, 2015: pp. 6-8.

${ }^{31}$ MoARD, "Ethiopian Food security program (2010-2014)," Ministry of Agriculture and Rural Development: Addis Ababa.

${ }^{32}$ Abduselam Abdulahi Mohamed, p. 92, 2017.
}

keadaan darurat. ${ }^{33}$ Tidak ada kepastian bahwa kekeringan adalah pendorong utama masalah kerawanan pangan di Etiopia, lebih banyak lagi bencana lain yang berkontribusi pada kerusakan pangan terkait dengan cuaca dan perubahan iklim saat ini. ${ }^{34}$

Dengan adanya kerawanan pangan di Etiopia, menimbulkan sebuah ancaman terhadap food security masyarakat Etiopia. Hal ini mendorong terganggunya salah satu aspek dari human security. Untuk melihat dampak krisis pangan terhadap human security, hal ini bisa di lihat dari sisi human development. Pada dasarnya, human security dan human development sangat berhubungan satu sama lainnya. Laporan human security bekerja lebih baik jika dikaitkan dengan konsep human lainnya, terutama human development. Contohnya meliputi: (1) memindahkan persepsi suatu masalah dari yang di dasarkan pada rasa takut menjadi melihatnya sebagai peluang; (2) memperkuat jembatan untuk tema human development melalui bekerja dengan konsep keamanan, yang menyangkut kemampuan orang untuk berkontribusi pada keamanan mereka sendiri, kemampuan untuk menghindari, dan mengatasi situasi ketidakamanan manusia; (3) menghindari sekuritisasi yang tidak perlu dari isu-isu yang dapat ditangani melalui perspektif kebutuhan manusia pada sistem kesejahteraan. ${ }^{35}$

Kemudian untuk melihat human development, dapat di gunakan Human Development Index (HDI), di mana berdasarkan HDI, krisis pangan yang terjadi di Etiopia dan memiliki hubungan dengan human security dapat dianalisis dari tiga dimensi, yaitu angka harapan hidup, standar hidup dan pendapatan, beserta tingkat pendidikan.

\footnotetext{
33 UNICEF, "Humanitarian Appel Report," Addis Ababa, 2015.

${ }^{34}$ Abduselam Abdulahi Mohamed, p. 93, 2017.

${ }^{35}$ Oscar A. Gomez and Des Gasper, "Human Security: A Thematic Guidance Note for Regional and National Human Development Report Teams," United Nations Development Programme Human Development Report Office, 2014: pp. 7.
} 


\section{c. Angka Harapan Hidup}

Berdasarkan HDI, salah satu indikator yang dapat digunakan untuk mengukur perkembangan human security di Etiopia adalah dengan melihat angka harapan hidup (life expectancy). Berdasarkan data yang didapat dari UNDP, nilai dari HDI Etiopia pada tahun 2015 adalah 0.448 yang membuat Etiopia berada pada salah satu negara dengan kategori perkembangan manusia terendah di dunia. Pasalnya, berdasarkan perhitungan UNDP, Etiopia berada pada peringkat ke 174 dari 188 negara yang ada di dunia. ${ }^{36}$

Walaupun nilai HDI Etiopia sangat rendah, secara mengejutkan angka harapan hidup dari masyarakat Etiopia sendiri semakin meningkat. Pasalnya, dari rentang waktu 15 tahun dari tahun 2000 sampai tahun 2015, angka harapan hidup masyarakat Etiopia naik sebanyak 17 setengah tahun dengan total ratarata ekspektasi harapan hidup sepanjang 64,6 tahun perorangnya.
Bila dikaji lebih mendalam, berdasarkan jenis kelamin, angka harapan hidup masyarakat Etiopia memiliki selisih sepanjang 5 tahun di mana wanita memiliki angka harapan hidup terpanjang sebanyak 66.6 tahun, sementara pria memiliki rata-rata angka harapan hidup sepanjang 62.7 tahun. Angka ini menunjukkan

bahwa krisis pangan yang melanda Etiopia tidak terlalu berpengaruh terhadap angka harapan hidup masyarakat Etiopia itu sendiri. ${ }^{37}$ Untuk data yang lebih jelas, perkembangan angka harapan hidup masyarakat Etiopia dapat diuraikan sebagai berikut:

\begin{tabular}{|c|c|}
\hline Tahun & Angka Hidup \\
\hline 2000 & 51.94 \\
\hline 2001 & 52.60 \\
\hline 2002 & 53.35 \\
\hline 2003 & 54.21 \\
\hline 2004 & 55.17 \\
\hline 2005 & 56.22 \\
\hline 2006 & 57.33 \\
\hline 2007 & 58.47 \\
\hline 2008 & 59.58 \\
\hline 2009 & 60.65 \\
\hline 2010 & 61.63 \\
\hline 2011 & 62.51 \\
\hline 2012 & 63.28 \\
\hline 2013 & 63.96 \\
\hline 2014 & 64.55 \\
\hline 2015 & 65.05 \\
\hline
\end{tabular}

Sumber:

Index Mundi, Ethiopia

Life Expectancy at birth

36 United Nations Development Programme, "Human Development for Everyone Briefing note for Countries on the 2016," Human Development Report: Ethiophia. 
Walaupun angka harapan hidup terlihat meningkat, namun sesungguhnya krisis pangan sangat berpengaruh terhadap human security di Etiopia sendiri. Hipotesis yang penulis dapat dari beberapa sumber memperlihatkan bahwa sebelum organisasi internasional dan bantuan asing secara aktif datang ke Etiopia, angka harapan hidup di Etiopia pada tahun 1990an hanya berkisar sepanjang 40-47 tahun. Dari tahun 2000 keatas, organisasi internasional seperti UNDP ikut berperan aktif dalam penanganan isu peningkatan kualitas hidup melalui berbagai program yang terkait dengan Sustainable Development Goals (SDGs). ${ }^{38}$

\section{d. Standar Hidup}

Dimensi kedua yang menjadi pertimbangan dari HDI adalah standar hidup masyarakat. Untuk mengukur standar ini, UNDP menggunakan Gross National Income (GNI). GNI merupakan total dari pendapatan yang dihasilkan oleh penduduk suatu negara baik di dalam maupun di luar negeri, di luar pendapatan asing. Menggunakan logaritma pendapatan, UNDP mengukur standar hidup masyarakat dari tahun ke tahun. ${ }^{39}$ Berdasarkan data yang didapat dari World Bank, Etiopia tergolong kepada negara Low National Income di mana Etiopia menduduki peringkat 75 dengan total rata-rata GNI nya adalah sebanyak 58,864 dollar pada tahun 2015. Walaupun krisis pangan terjadi di Etiopia, secara mengejutkan pertumbuhan GNI di Etiopia sendiri justru semakin meningkat dari tahun ke tahun. Untuk lebih lengkapnya, data pertumbuhan GNI Etiopia dapat digambarkan sebagai berikut:

38 Website: United Nations Development Programme. Sustainable Development Goals: What are the proposed Global Goals?. UNDP in Ethiopia. Diambil dari https://www.et.undp.org/content/ethiopia/en/home/ SDG.html (diakses pada 31 Agustus 2019).

39 Website: United Nations Development Programme. Human Development Index (HDI). Human Development Reports. Diambil dari http://hdr.undp.org/en/content/human-developmentindex-hdi (diakses pada 31 Agustus 2019). 
GNI Etiopia Tahun 2000-2017

\begin{tabular}{|c|c|}
\hline Tahun & GNI (dalam US Dolar) \\
\hline 2000 & 130 \\
\hline 2001 & 130 \\
\hline 2002 & 120 \\
\hline 2003 & 110 \\
\hline 2004 & 140 \\
\hline 2005 & 160 \\
\hline 2006 & 180 \\
\hline 2007 & 220 \\
\hline 2008 & 280 \\
\hline 2009 & 340 \\
\hline 2010 & 380 \\
\hline 2011 & 390 \\
\hline 2012 & 410 \\
\hline 2013 & 470 \\
\hline 2014 & 550 \\
\hline 2015 & 600 \\
\hline 2016 & 670 \\
\hline 2017 & 740 \\
\hline
\end{tabular}

Sumber: The World Bank

\section{UNDP melaporkan bahwa kehidupan} masyarakat Etiopia memiliki indeks kemiskinan multidimensional yang sangat tinggi. Dimensi yang dimaksud ialah ketidakmampuan mereka dalam memenuhi kebutuhan pendidikan, kesehatan, dan standar hidup. Berdasarkan data yang didapat pada tahun 2011, 88\% dari masyarakat Etiopia menderita kemiskinan multidimensional ini. Walaupun kekeringan dan krisis pangan menurunkan standar hidup masyarakat Etiopia, akan tetapi bila dilihat dari segi GNI, krisis pangan tidak berpengaruh pada standar hidup masyarakat Etiopia. ${ }^{40}$

\section{e. Pendidikan}

Dimensi ketiga dalam pertimbangan HDI adalah dari segi pendidikan. Pendidikan merupakan tolak ukur terpenting dalam

\footnotetext{
${ }^{40}$ United Nations Development Programme, Human Development for Everyone Briefing note for Countries on the 2016, Human Development Report: Ethiophia.
}

menentukan kesejahteraan masyarakat di suatu negara. Dalam HDI, pendidikan di suatu negara terdapat beberapa kategori penilaian, diantaranya adalah: ${ }^{41}$

- Rata-rata lama sekolah;

- Angka melek huruf;

- Angka partisipasi murni Sekolah Dasar;

- Angka partisipasi murni Sekolah Menengah Pertama;

- Angka partisipasi siswa Sekolah Menengah Atas;

- Persentase penduduk usia 15 tahun keatas tamat Sekolah Menengah Pertama;

- Murid per bangku sekolah;

- Jumlah penduduk usia sekolah. Dengan adanya kategori penilaian diatas, peneliti mendapatkan data dari UNDP yang

${ }^{41}$ M. Faqihudin, "Human Development Index (HDI) Salah Satu Indikator Yang Populer Untuk Mengukur Kinerja Pembangunan Manusia," Jurnal Cermin, p. 9. September 2010. 
menyatakan bahwa pendidikan di Etiopia diukur dari hanya empat kategori saja, yaitu: ${ }^{42}$

- Angka melek huruf

Lebih dari 20 juta penduduk Etiopia masih belum bisa membaca dan menulis. Hal ini menunjukkan bahwa tingkat literasi di Etiopia masih tergolong sangat rendah.

- Angka partisipasi siswa Sekolah Dasar Pendidikan di Etiopia untuk anak-anak sekolah dasar mendapat perhatian yang cukup dari pihak pemerintah yang menginginkan penerapan universal primary education. Hal ini terbukti bahwa meningkatnya kesadaran masyarakat akan pentingnya pendidikan, terutama kemampuan membaca dan menulis. Pemerintah Etiopia sendiri sadar akan pentingnya pendidikan bagi anak-anak kecil dan pendaftaran anak-anak memasuki sekolah dasar hampir mengalami peningkatan 3 kali lipat sejak diadakannya monitoring pada tahun 1994.

- Angka partisipasi pada secondary school (SMP dan SMA)

Pendidikan secondary school di Etiopia mengalami peningkatan, tetapi masih dikatakan berada pada posisi bawah, khususnya yang terdapat pada area perkampungan miskin.

- Jumlah penduduk usia sekolah. Dalam sumber yang peneliti peroleh tidak dijelaskan bahwa jumlah penduduk usia sekolah, namun yang dijelaskan adalah adanya kurikulum dan peningkatan pendidikan bagi orang dewasa, dan pemerintah juga menyediakan sarana pendidikan pada 3,5 juta orang dewasa di Etiopia pada tahun 2012-2013.

Laporan Save the Children menunjukkan bahwa krisis pangan

42 United Nations Development Programme, "National Human Development Report 2014 Ethiopia, pp. 31-46. memberikan dampak terhadap pendidikan, khususnya kepada anak-anak. Tepatnya pada saat Etiopia telah membuat langkah signifikan dalam meningkatkan akses anak ke pendidikan yang berkualitas dan inklusif. Di seluruh wilayah yang terkena dampak kekeringan, anak-anak tidak lagi bersekolah secara teratur, jika tidak putus sekolah sama sekali, akibat kekeringan. Sementara anak-anak putus sekolah karena berbagai alasan, dua faktor umum seperti kekurangan makanan dan air yang kronis, mendorong anak-anak menjauh dari kelas mereka dan menempatkan perlindungan dan perkembangan mereka dalam resiko. ${ }^{43}$ Namun di sisi lain, krisis pangan jika di ukur melalui HDI pada tingkat pendidikan, menyatakan bahwa krisis pangan tidak memiliki dampak terhadap pendidikan di Etiopia. Pasalnya, yang membuat tingkat pendidikan rendah di Etiopia disebabkan oleh minimnya pendidikan yang diterima di sekolah, dan yang level literasi yang rendah di mana 20 juta orang Etiopia tidak bisa membaca dan menulis.

\section{Kesimpulan}

Berdasarkan Human Development Report tahun 1994, ancaman terhadap human security sangat banyak, walaupun begitu indikatornya dibagi menjadi tujuh aspek utama yang telah dipaparkan sebelumnya. Pada artikel ini berfokus kepada food security yang merupakan salah satu indikator dari human security di mana hal tersebut terancam kondisinya di Etiopia karena adanya kekeringan dan El Nino yang menyebabkan kelaparan di Etiopia.

Dalam jangka pendek, ditemukan bahwa krisis pangan yang melanda Etiopia mengganggu human security dikarenakan menyebabkan jatuhnya korban jiwa, penyakit, dan malnutrisi. Hal ini dilihat dari faktor food security sebagai bagian dari human security menjadi terancam. Sementara itu, untuk

\footnotetext{
${ }^{43}$ Save the Children, "Mitigating Ethiopia's Drought Impacts on Children Through Education," 2016: p. 1.
} 
mengukur dampak krisis yang lebih jauh, HDI digunakan sebagai instrumen pengukurnya. Dari tiga dimensi utama ukuran HDI, didapati bahwa krisis pangan yang melanda Etiopia tidak berpengaruh terhadap human security Etiopia sendiri. Pasalnya, dari tahun ke tahun, walaupun dilanda oleh krisis pangan, angka harapan hidup, GNI, dan pendidikan Etiopia meningkat. Karena ditemukan bahwa human development dan human security saling terkait tetapi sama sekali tidak identik. Human development adalah konsep yang luas, yang bertujuan untuk memperbesar pilihan dan kebebasan orang. Human security adalah tentang memastikan kebebasan prioritas sehingga "orang dapat menjalankan pilihan dengan aman dan bebas" dan dapat yakin bahwa peluang yang mereka miliki dilindungi. ${ }^{44}$

Hal yang menarik dapat dilihat ketika human security dan human development sebagai bagian dalam mengukur human security serta memiliki hubungan di dalamnya justru menghasilkan analisis berbeda. Jika krisis pangan yang melanda Etiopia, dianggap sebagai terganggunya human security di Etiopia jika dilihat lewat konsep human security yang dipaparkan oleh UNDP. Namun di balik terganggunya human security menurut UNDP di Etiopia, justru tidak menjadi sesuatu hal yang memiliki dampak terhadap human security Etiopia sendiri yang dilihat dari analisis melalui kerangka HDI yang merupakan kerangka human development dan bagian dari aspek mengukur human security.

Kemudian saran dan harapan peneliti dalam artikel ini ialah adanya kedepan pemaparan atau penelitian lebih lanjut mengenai hal yang menarik tersebut. Khususnya, pada hal di mana krisis pangan yang terjadi di Etiopia justru belum memberikan pengaruh yang berarti terhadap Etiopia jika diukur dari HDI dan mengapa hal tersebut bisa terjadi, di sisi lain HDI dan human security saling berkaitan satu sama

\footnotetext{
${ }^{44}$ Oscar A. Gomez and Des Gasper, 2014: p. 3.
}

lainnya, walaupun terdapat beberapa perbedaan.

\section{Daftar Pustaka}

Alli, A. M., Winter, G. S., \& May, D. L. (2007). Globalization: Its Effects. International Business \& Economics Research Journal 6(1): 89-96.

Anand, S., \& Sen, A. (2000). The Income Component of the Human Development Index. Journal of Human Development , 1, no. 1, 83-106.

Anderson, S., \& Farmer, E. (2015). USAID Office of Food for Peace Food Security Country Framework for Ethiopia FY 2016-FY 2020. Washington, D.C.: Food Economy Group.

Burhan, R. (Ed.). (3 Oktober 2015). Sekitar 7,5 juta penduduk Ethiopia kelaparan akibat El Nino. Antaranews.com. Diambil dari https://www.antaranews.com/berita/521 422/sekitar-75-juta-penduduk-ethiopiakelaparan-akibat-el-nino (Diakses pada 28 Agustus 2019).

Clover, J. (2003). Food Security in Sub- Saharan Africa. African Security Review 12(1): 5-15.

Faqihudin, M. (2010). Human Development Index (HDI) Salah Satu Indikator Yang Populer Untuk Mengukur Kinerja Pembangunan Manusia. Jurnal Cermin, $1-16$.

Food Agriculture Organization. (Juni 2006). Food Security. Policy Brief, 1-4.

Food and Agriculture Organization of the United Nations. (2016). Human Security \& Food Security. United Nations Human Security Unit. 1-10.

Food and Agriculture Organization of United Nations. (Juli 2016). 2015-2016 El Niño: Early Action and Response for Agriculture, Food Security and Nutrition. Working Draft, 1-40.

Food and Agriculture Organization. (24 Februari 2016). El Niño in Ethiopia: Programme Observations on the Impact of the Ethiopia Drought and Recommendations for Action. OXFAM El Niño Briefings, 1-11.

Gomez, O. A., \& Gasper, D. (2014). Human Security: A Thematic Guidance Note for Regional and National Human Development Report Teams. United Nations Development Programme 
Human Development Report Office, 116.

Human Development Report. (2016). Technical Notes, Calculating the Human Development Indices-Graphical Presentation. 1-14.

Index Mundi. (2015). Ethiopia Life Expectancy at birth. Diambil dari https://www.indexmundi.com/facts/ethio pia/life-expectancy-at-birth (Diakses pada 31 Agustus 2019).

Kloos, H., \& Lindtjørn, B. (1994). Malnutrition During Recent Famines in Ethiopia. Northeast African Studies, 1, no.1, 121136.

Kpolovie, P. J., Ewansiha, S , dan Esara, M. (Januari 2017). Continental Comparison of Human Development Index (HDI). International Journal of Humanities Social Sciences and Education (IJHSSE) 4, no. 1, 9-27.

Malk, B. Y. (2017). State-induced Famine in Eritrea: Persecution and Crime against Humanity. Journal of Politics and Law 10(4): 1-14.

Miller, M. (n.d). Hunger in Ethiopia. https://www.worldfoodprize.org/docume nts/filelibrary/images/youth_programs/re search papers/2005 papers/NewLondon HighSchool_8D8BFDC1AE320.pdf (Diakses pada 28 Agustus 2019).

MoARD. (n.d). Ethiopian Food security program (2010- 2014). Addis Ababa: Ministry of Agriculture and Rural Development.

Mohamed, A. A. (2017). Food Security Situation in Ethiopia: A Review Study. International Journal of Health Economics and Policy 2(3): 86-96.

Ncube, M., Lufumpa, C. L., Mugerwa, S. K., \& Murinder, V. (2014). Africa Food Security Brief: Special focus on climate Africa Food Security change Impacts. Africa Food Security Special focus on climate change Impacts Statistics Department Issue no. 5. 1-20.

Save the Children. (2016). Mitigating Ethiopia's Drought Impacts on Children Through Education. 1-7.

Schadomsky, L., \& Legowo-Zipperer , V. (22 Juli 2011). Krisis Kelaparan di Ethiopia. (H. Pasuhuk, Ed.) Dw News. Diambil dari http://www.dw.com/id/krisis- kelaparan-di-ethiopia/a-15259579

(Diakses pada 29 Agustus 2019).

Solomon, S. (15 Agustus 2017). Oxfam: 700,000 at Risk of Starvation in Ethiopia.

Dalam

https://www.voanews.com/africa/oxfam700000-risk-starvation-ethiopia, diakses tanggal 7 Oktober 2020.

UNICEF. (2015). Humanitarian Appel Report. Addis Ababa.

United Nations Development Programme, Human Development for Everyone Briefing note for Countries on the 2016. Human Development Report: Ethiophia. United Nations Development Programme. (1994). New Dimensions of Human Security. New York: Oxford University Press.

United Nations Development Programme. (1994). Human Development Report 1994. New York: Oxford University Press.

United Nations Development Programme. (2015). Human Development Report 2015 (pp. 5-6). New York: RR Donnelley Company.

United Nations Development Programme. Human Development Index (HDI). Human Development Reports. Diambil dari

http://hdr.undp.org/en/content/humandevelopment-index-hdi (Diakses pada 31 Agustus 2019).

United Nations Development Programme. National Human Development Report 2014 Ethiopia. 1-97.

United Nations Development Programme. Sustainable Development Goals: What are the proposed Global Goals? UNDP in Ethiopia. Diambil dari https://www.et.undp.org/content/ethiopi a/en/home/SDG.html (Diakses pada 31 Agustus 2019).

United Nations International Children's Emergency Fund. (April 2016). Ethiopia El Nino Emergency. Fast Facts.

United Nations Trust Fund for Human Security. (2009). Human Security in Theory and Practice: An Overview of the Human Security Concept and the United Nations Trust Fund for Human Security. New York: Human Security Unit United Nations. 
United Nations Trust Fund for Human Security. (2016). Human Security Handbook: An integrated approach for the realization of the Sustainable Development Goals and the priority areas of the international community and the United Nations system. Human Security Unit United Nations.

USAID. (21 Agustus 2019). Food Assistance Fact Sheet Ethiopia.

World Food Programme. (24 Juni 2013). 10 Things Everyone Should Know About Hunger In Ethiopia. Diambil dari https://www.wfp.org/stories/10-thingseveryone-should-know-about-hungerethiopia (Diakses pada 29 Agustus 2019).

World Vision International. Responding to Food Insecurity in Ethiopia - March 2018. (20 April 2018). World Vision Online, Dalam https://www.wvi.org/ethiopia/publicatio $\mathrm{n} /$ responding-food-insecurity-ethiopiamarch2018\#: :text=A\%20total\%20of\%20105 $\% 2 \mathrm{C} 239 \% 20$ people,food\%20insecurity $\% 20$ in $\% 20$ March\%202018.\&text=The\% 20nutrition $\% 20$ needs $\% 20$ are $\% 20$ caused, persons $\% 20$ and $\% 20$ high $\% 20$ food $\% 20$ in security.; diakses tanggal 7 Oktober 2020. 